\title{
AN INVESTIGATION OF THE PREVALENCE AND SIGNIFICANCE OF GASTRIC PARIETAL-CELL AUTOANTIBODY IN RHEUMATOID ARTHRITIS
}

\author{
BY \\ ERNEST M. ARMSTRONG \\ Fourth Year Medical Student, Centre for Rheumatic Diseases, Glasgow
}

Anti-gamma globulin autoantibodies or rheumatoid factors have been detected in the serum of approximately 70-80 per cent. of patients with rheumatoid arthritis (RA) (Ziff, 1957; Glynn and Holborow, 1960; Singer, 1961; Vaughan and Butler 1962), and antinuclear autoantibodies or factors have been detected in approximately 30 per cent. of patients with the disease (Alexander, Bremner, and Duthie, 1960; Hall, Bardawil, Bayles, Mednis, and Galins, 1960; Beck, 1963; Ward, Johnson, and Holborow, 1964; Pitkeathly and Taylor, 1967). In addition to these non-organ-specific autoantibodies, some workers (Anderson, Goudie, Gray, and Buchanan, 1961; Buchanan, Crooks, Alexander, Koutras, Wayne, and Gray, 1961 ; Becker, Ferguson, and McConahey, 1963; Becker, Titus, Woolner, and Ferguson, 1963; Kornstad and Kornstad, 1964) but not all (Hijmans, Doniach, Roitt, and Holborow, 1961; Masi, Hartmann, Hahn, Abbey, and Shulman, 1965; Mulhern, Masi, and Shulman, 1966) have noted an increased prevalence of organ-specific thyroid autoantibodies and chronic thyroiditis in patients with RA. The position regarding the prevalence of gastric parietal-cell autoantibodies in RA is not clear, although Roitt, Doniach, and Shapland (1965) have noted that the "incidence is only slightly raised above that of controls".

The first purpose of this study was to define the prevalence of gastric parietal-cell autoantibody in patients with $\mathrm{R}:$ and to compare this with the prevalence found in patients with other forms of arthritis, such as osteo-arthritis, Reiter's disease, psoriatic arthritis, ankylosing spondylitis, and gout. The second purpose of the study was to determine whether the gastric parietal-cell autoantibody found in some patients with RA resulted from a non-organspecific autoantibody which stained the cytoplasm of gastric parietal cells, or whether it was organspecific as in pernicious anaemia (Irvine, Davies,
Delamore, and Wynn Williams, 1962; Markson and Moore, 1962; Taylor, Roitt, Doniach, Couchman, and Shapland, 1962; Irvine 1965) and iron deficiency anaemia (Markson and Moore, 1962; Dagg, Goldberg, Anderson, Beck, and Gray, 1964) and associated with chronic atrophic gastritis.

\section{Patients Studied \\ Material and Methods}

Gastric parietal-cell autoantibody was studied in the sera of 325 patients with "probable", "definite", and "classical" RA as defined by the American Rheumatism Association criteria (Ropes, Bennett, Cobb, Jacox, and Jessar, 1959) and in the sera of 231 patients with osteoarthritis, fifteen with Reiter's disease, fourteen with psoriatic arthritis, twelve with gout, and three with ankylosing spondylitis. The age and sex distribution of these patients is shown in Table I (overleaf).

\section{Immunofluorescence}

The gastric parietal-cell autoantibody was studied by an immunofluorescent sandwich technique described by Adams, Glen, Kennedy, Mackenzie, Morrow, Anderson, Gray, and Middleton (1964). The serum was tested undiluted against $5 \mu$. cryostat sections of the body of fresh human stomach obtained at operation for peptic ulcer. Sections were randomly dispersed within large batches of routine slides in the immunopathology laboratory and read by the author and by another two experienced, independent observers. Only stronglypositive staining was considered indicative of the presence of the autoantibody.

\section{Specificity of Autoantibody}

26 patients with RA were selected for further study. Twelve had positive tests for gastric parietal-cell autoantibody, and the specificity of their serum was checked in a dilution of 1 in 16 using $5 \mu$. cryostat sections of rat kidney and in a dilution of 1 in 4 using $5 \mu$. cryostat sections of fresh human thyroid gland obtained at thyroidectomy, as recommended by Roitt, Doniach, and Shapland (1965). The remaining fourteen had negative 
TABLE I

PREVALENCE OF GASTRIC PARIETAL CELL AUTOANTIBODY IN PATIENTS WITH RHEUMATOID ARTHRITIS AND VARIOUS OTHER ARTHRITIDES

\begin{tabular}{|c|c|c|c|c|c|c|c|c|c|c|}
\hline \multirow{2}{*}{\multicolumn{5}{|c|}{ Diagnosis }} & \multirow[t]{2}{*}{$\operatorname{Sex}$} & \multicolumn{2}{|c|}{ Age (yrs) } & \multirow[t]{2}{*}{$\begin{array}{l}\text { Number of } \\
\text { Patients }\end{array}$} & \multicolumn{2}{|c|}{$\begin{array}{c}\text { Positive Immunofluorescent } \\
\text { Tests for Gastric Parietal- } \\
\text { Cell Autoantibody }\end{array}$} \\
\hline & & & & & & Mean & Range & & Number & Percent. \\
\hline \multirow[t]{2}{*}{ Rheumatoid Arthritis } & \multirow{2}{*}{$\cdots$} & \multirow{2}{*}{$\cdots$} & \multirow{2}{*}{$\cdots$} & & Female & $49 \cdot 4$ & $6-81$ & 246 & 40 & $16 \cdot 2$ \\
\hline & & & & & Male & $42 \cdot 7$ & $18-73$ & 79 & 5 & $6 \cdot 3$ \\
\hline \multirow[t]{2}{*}{ Osteo-arthritis. . } & \multirow[t]{2}{*}{$\cdots$} & \multirow[t]{2}{*}{$\cdots$} & \multirow[t]{2}{*}{$\cdots$} & \multirow[t]{2}{*}{$\cdots$} & Female & $60 \cdot 2$ & $23-74$ & 141 & 24 & $17 \cdot 0$ \\
\hline & & & & & Male & $51 \cdot 6$ & $42-64$ & 90 & 0 & $0 \cdot 0$ \\
\hline Reiter's Disease & . & . & $\cdots$ & . & Male & $29 \cdot 3$ & $17-55$ & 15 & 0 & $0 \cdot 0$ \\
\hline \multirow[t]{2}{*}{ Psoriatic Arthritis } & \multirow{2}{*}{$\cdots$} & \multirow{2}{*}{$\cdots$} & \multirow{2}{*}{$\cdots$} & \multirow{2}{*}{$\cdots$} & Female & $43 \cdot 6$ & $20-65$ & 12 & 1 & $9 \cdot 3$ \\
\hline & & & & & Male & $38 \cdot 0$ & $29-47$ & 2 & 0 & $0 \cdot 0$ \\
\hline \multirow[t]{2}{*}{ Gout } & \multirow[t]{2}{*}{. } & \multirow{2}{*}{$\cdots$} & \multirow{2}{*}{$\cdots$} & \multirow[t]{2}{*}{$\cdots$} & Female & $59 \cdot 0$ & $59-59$ & 2 & 1 & $50 \cdot 0$ \\
\hline & & & & & Male & $53 \cdot 3$ & $36-83$ & 10 & 0 & $0 \cdot 0$ \\
\hline Ankylosing Spondylitis & & . & . & . & Male & $46 \cdot 3$ & $38-45$ & 3 & 0 & $0 \cdot 0$ \\
\hline
\end{tabular}

tests for gastric parietal-cell autoantibody and were used as controls.

The clinical and laboratory data are summarized in Table II, and details of drug therapy in these two groups are shown in Table III (opposite).

Both groups were well matched for age and sex, duration of arthritis, articular index (co-operating Clinics Committee of the American Rheumatism Association, 1965), presence of subcutaneous nodules, positive sheep cell agglutination tests (SCAT) (Heller, Jacobson, Kolodny, and Kammerer, 1954), antinuclear factor (ANF) tests (Beck, 1961), serum globulin levels, and haemoglobin concentrations. The control patients with negative tests for gastric parietal-cell autoantibodies had significantly lower serum albumin levels $(t=3 \cdot 175$; $\mathbf{P}<\mathbf{0 . 0 1 )}$ and significantly higher erythrocyte sedimentation rates $(t=2.205 ; \mathrm{P}<0.05)$. The two groups were comparable with regard to drug therapy (Table III). although significantly more of the patients with gastric parietal-cell autoantibody in their serum had received phenylbutazone therapy in the past $\left(\chi^{2}=6.527\right.$; $\mathbf{P}<0 \cdot 01)$.

\section{Gastric Function Tests}

Augmented histamine test meals (Kay, 1953) were carried out by the following technique.

After an overnight fast, a No. 16 gauge radio-opaque tube (Neoplex, Rayx, Porges, France) was passed per nasam into the stomach. The patient was placed comfortably on the left side and the tube manoeuvred while hand suction was applied until the position of maximum drainage was ascertained. The tube was then fixed in position and continuous suction of 5-10 $\mathrm{mm}$. $\mathrm{Hg}$ was applied using a continuous suction pump.* The position of the tube was confirmed radiologically in two patients in the test group (Cases 2 and 12) and two controls (Cases 3 and 4). The tubes were checked regularly during the test to ensure patency.

After the gastric tube had been passed the stomach contents were aspirated for 30 minutes and discarded. The aspirate over the next 30 minutes was collected and represented basal acid secretion.

* Hy-Flo continuous suction pump, Down Bros. and Mayer and Phelps Ltd., Mitcham, England.

CLINICAL AND LABORATORY DATA IN TWELVE PATIENTS WH

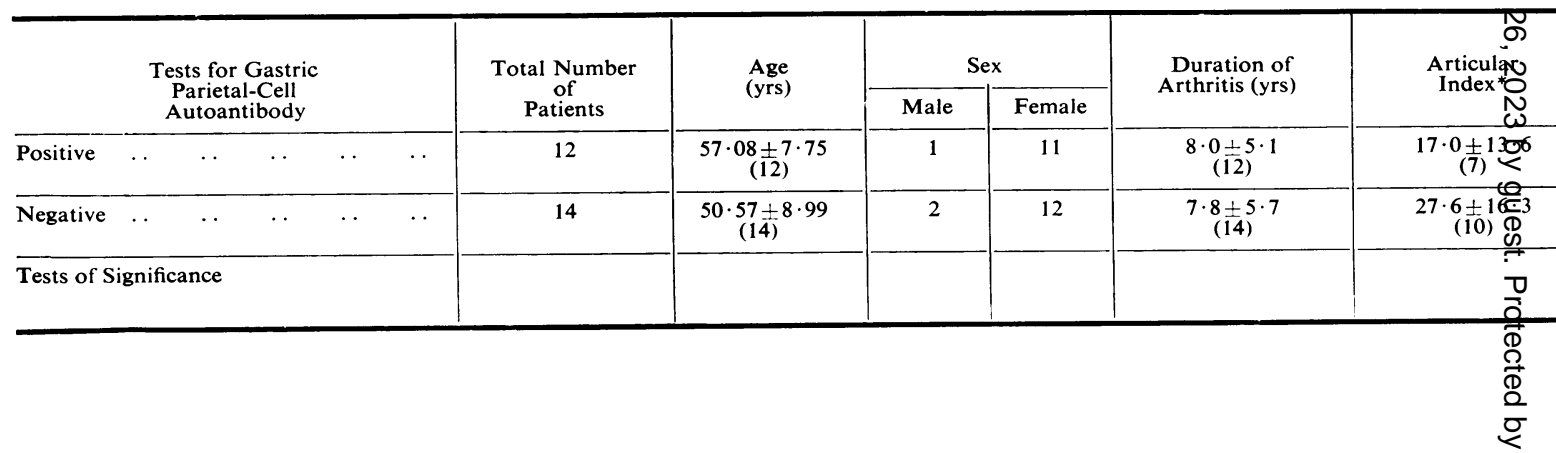


TABLE III

DRUG THERAPY

\begin{tabular}{|c|c|c|c|c|c|c|c|c|}
\hline \multirow{2}{*}{$\begin{array}{c}\text { Tests for Gastric } \\
\text { Parietal-Cell } \\
\text { Autoantibody } \\
\text { (12) }\end{array}$} & \multicolumn{8}{|c|}{ Drug } \\
\hline & Aspirin & Paracetamol & Phenylbutazone & Indomethacin & Gold & Steroids & Iron & Vitamin $\mathbf{B}_{12}$ \\
\hline Positive (12) & 11 & 4 & 11 & 6 & 3 & 6 & 4 & 3 \\
\hline Negative (14) & 14 & 5 & 5 & 5 & 0 & 9 & 2 & 1 \\
\hline $\begin{array}{l}\text { Tests of } \\
\text { Significance }\end{array}$ & & & $\begin{array}{c}x^{2}=6.527 \\
P<0.01\end{array}$ & & & & & \\
\hline
\end{tabular}

Mepyramine malleate $\dagger 100 \mathrm{mg}$. was then administered intramuscularly, and $0.04 \mathrm{mg} . / \mathrm{kg}$. body weight of histamine acid phosphate B.P. $\ddagger$ was given by subcutaneous injection 30 minutes later. Gastric aspiration was continued during this time and for a further 15 minutes after administration of the histamine: this aspirate was discarded. The aspirate collected during the subsequent 30 minutes represented the maximum acid secretion (Kay, 1953).

The $\mathrm{pH}$ of both gastric juice specimens was measured using a glass electrode, and $10 \mathrm{ml}$. aliquots of the aspirates were titrated against standard $\mathrm{N} / 10 \mathrm{NaOH}$ using Topffer's reagent and Phenol red as indicators, thus giving a measure of free and total acidity. The free acid is hydrochloric acid and the total acid includes the contribution by acid mucoprotein residues and organic acids. The maximal free acid secretion has been shown to correlate with total parietal-cell mass both in human beings (Card and Marks, 1960) and in dogs (Marks, Komarov, and Shay, 1960).

\section{Statistical Methods}

Data were analysed either by a standard Student's " $t$ " test or by a $\chi^{2}$ analysis. Where small numbers were involved in the $\chi^{2}$ analysis, Yates's correction for continuity was employed.

\section{Results}

Prevalence of Gastric Parietal-cell Autoantibody in Arthritic Patients

Table I shows that the prevalence of positive tests for gastric parietal-cell autoantibody in female patients with "probable", "definite", and "clas-

$\dagger$ Anthisan, May and Baker Ltd., Dagenham, Essex.

‡ Evans Ltd., Speke, Liverpool. sical" RA ( $16 \cdot 2$ per cent.) is similar to that in female patients with osteo-arthritis (17 per cent.). Five of the 79 male patients with RA had positive tests for gastric parietal-cell autoantibody, whereas none of ninety male patients with osteo-arthritis had positive tests; these differences are, however, not significant. There was a low prevalence of gastric parietal-cell autoantibodies in patients with other arthritides.

\section{Specificity of Gastric Parietal-cell Autoantibody in Patients with RA}

The results of the immunofluorescent tests for nonspecific autoantibody reacting with rat kidney tubules and human thyroid epithelium in twelve patients with RA and positive tests for gastric parietal-cell autoantibody are as follows:

None of the twelve sera showed fluorescence with rat kidney tubules. A positive test with human thyroid epithelium was seen in one serum and a weak positive reaction in a further two. In each of these three cases, however, the staining was of the specific type, being finely granular and being confined to the epithelial cells. Thus no evidence was found for any non-specific autoantibody in any of these twelve patients.

Correlation of Presence of Gastric Parietal-cell Autoantibody with Gastric Secretory Function in Patients with RA

The results of the augmented histamine test meals in the twelve patients with RA who had

AND POSITIVE TESTS AND IN FOURTEEN PATIENTS WITH RA AND NEGATIVE TESTS

\begin{tabular}{|c|c|c|c|c|c|c|}
\hline $\begin{array}{l}\text { Number with } \\
\text { Subcutaneous } \\
\text { Nodules }\end{array}$ & $\begin{array}{c}\text { Sheep Cell } \\
\text { Agglutination } \\
\text { Test } \\
\text { Positive }\end{array}$ & $\begin{array}{c}\text { Immunofluorescent } \\
\text { Test for } \\
\text { Antinuclear Factor } \\
\text { Positive }\end{array}$ & $\begin{array}{c}\text { Serum } \\
\text { Albumin } \\
\text { (g. } / 100 \mathrm{ml} .)\end{array}$ & $\begin{array}{c}\text { Serum } \\
\text { Globulin } \\
\text { (g./100 ml.) }\end{array}$ & $\begin{array}{c}\text { Erythrocyte } \\
\text { Sedimentation } \\
\text { Rate (Westergren) } \\
\text { (mm./hr) }\end{array}$ & $\begin{array}{l}\text { Haemoglobin } \\
\text { Concentration } \\
\text { (g. } / 100 \mathrm{ml} .)\end{array}$ \\
\hline $\begin{array}{c}0 \\
(7)\end{array}$ & $\begin{array}{c}8 \\
(11)\end{array}$ & $\begin{array}{c}6 \\
\text { (11) }\end{array}$ & $\begin{array}{c}3 \cdot 6 \pm 0 \cdot 5 \\
(10)\end{array}$ & $\begin{array}{c}3 \cdot 6 \pm 0 \cdot 6 \\
(1 \mathrm{p})\end{array}$ & $\begin{array}{c}27 \cdot 2 \pm 24 \cdot 7 \\
(9)\end{array}$ & $\begin{array}{c}13 \cdot 0 \pm 1 \cdot 4 \\
(9)\end{array}$ \\
\hline \multirow[t]{2}{*}{$\begin{array}{c}3 \\
(10)\end{array}$} & (13) & $\begin{array}{c}5 \\
(14)\end{array}$ & $\begin{array}{c}3 \cdot 0 \pm 0 \cdot 4 \\
(14)\end{array}$ & $\begin{array}{c}3 \cdot 7 \pm 0 \cdot 6 \\
(14)\end{array}$ & $\begin{array}{c}57 \cdot 2 \pm 40 \cdot 5 \\
(14)\end{array}$ & $12 \cdot 6 \pm 1 \cdot 4$ \\
\hline & & & $\begin{aligned} & t=3.746 \\
& \mathrm{P}<0.01\end{aligned}$ & & $\begin{array}{l}t=2.205 \\
\mathrm{P}<0.05\end{array}$ & \\
\hline
\end{tabular}


positive tests for gastric parietal-cell autoantibody and the fourteen controls are shown in Table IV. Eleven of the twelve positive patients had no detectable free or total acid in the basal specimen, whereas only six of the fourteen controls had achlorhydria in the basal specimen. These differences are, however, not significant. The differences between the two groups are more marked in the post-histamine specimens. If histamine-fast hypochlorhydria is defined as $\leqslant 2.0 \mathrm{mEq} / \mathrm{hr}$ of maximal free acid secretion in the post-histamine hour, then it can be seen that nine of the twelve positive patients and only two of the fourteen controls had hypochlorhydria. These differences are significant $\left(\chi^{2}=7.429 ; \quad P<0.05\right)$. No correlation was found between any current or past drug therapy, in particular oral analgesics and the results of the augmented histamine test, but the numbers involved in the two groups, are, of course, too small to allow any concrete statistical analysis of this point.

TABLE IV

RESULTS OF AUGMENTED HISTAMINE TEST MEALS

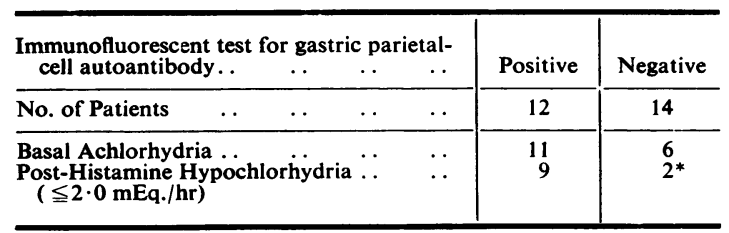

$*^{2}=7 \cdot 429 ; \mathrm{P}<0.05$

\section{Discussion}

Although there is some evidence for an increased prevalence of organ-specific thyroid autoantibodies and chronic thyroiditis in patients with RA, the present study has shown no evidence of an increased prevalence of gastric parietal-cell autoantibodies (Table I). These observations are consistent with those of Roitt and others (1965), who also found no significant increase in prevalence of gastric parietalcell autoantibody. It is of interest, however, that an increase prevalence of gastric parietal-cell autoantibodies has been observed in Glasgow in female patients with Sjögren's syndrome (Goudie and Buchanan, 1967), although no increased prevalence was noted in the serum of patients with Sjögren's syndrome diagnosed by the same criteria at the National Institutes of Health, Bethesda, Maryland, U.S.A., when tested in the same laboratory in Glasgow (Anderson, Beck, Bloch, Buchanan, and Bunim, 1965).

Gastric parietal-cell autoantibody is found in the serum of over 80 per cent. of patients with pernicious anaemia (Irvine and others, 1962; Taylor and others, 1962; Bernhardt, Burkett, Fields, and Killian, 1965; De Boer, Nairn, and Maxwell, 1965) and is also commonly found in the serum of patients suffering from a variety of other autoimmune diseases, such as autoimmune thyroiditis (Doniach, Roitt, and Taylor, 1963; Irvine, 1966), thyrotoxicosis (Doniach and others, 1963), and iron deficiency anaemia (Markson and Moore, 1962; Dagg and others, 1964), as well as in miscellaneous conditions such as diabetes mellitus (Moore and Neilson, 1963), and in a proportion of apparently healthy people. Where the autoantibody is present in the absence of pernicious anaemia, gastric mucosal biopsy invariably reveals chronic atrophic gastritis associated with varying degrees of impairment of gastric secretion following maximal histamine stimulation (Irvine, 1965; Adams and others, 1964; Irvine, Davies, Teitelbaum, Delamore, and Wynn Williams, 1965; Coghill, Doniach, Roitt, Mollin, and Wynn Williams 1965; Williams, Scott, Beck, and Blair, 1966).

In twelve positive patients who had no non-organ specific autoantibody demonstrable by testing against rat kidney and human thyroid (Roitt and others, 1965), a significant impairment of gastric acid secretion as detected by the augmented histamine test meal (Kay, 1953) was demonstrated as compared with fourteen controls matched for age and sex. (The fact that the control patients were in a more active phase of the disease as shown by hypoalbuminaemia and raised erythrocyte sedimentation rate was not considered to have influenced the results of the augmented histamine test meals.) This presumably reflects chronic atrophic gastritis in these patients with gastric parietal-cell autoantibodies, since there is evidence that the degree of hypochlorhydria is related to the viable parietal-cell mass and to the extent of chronic atrophic gastritis (Card and Marks, 1960; Marks and others, 1960; Irvine, 1966). It was not felt justified to submit these patients to the inconvenience and potential hazard of gastric mucosal biopsy to prove this point completely.

The oral analgesic and corticosteroid drugs used in the treatment of RA are known to influence gastric function (Kirsner and Ford, 1955; Mauer, 1955; Weiss, Pitman, and Graham, 1961; Scott, Porter, Lewis, and Dixon, 1961; Ballabio, Cirla, Girardi, Caruso, and Colombo, 1963; Rothermich, 1966), but in the present study there was no correlation between the past or present administration of any one drug and the results of the augmented histamine test meals, although the numbers involved preclude any statistical analysis of this point. 
It is concluded that there is no increased prevalance of gastric parietal-cell autoantibodies in RA patients, but that when such autoantibodies are found they are organ-specific and are related to chronic atrophic gastritis with impairment of gastric acid secretory function. Further studies would be of interest to determine the relationship of gastric parietal-cell autoantibodies to latent pernicious anaemia in patients suffering from RA.

\section{Summary}

The prevalence of gastric parietal-cell autoantibody was studied in patients with rheumatoid arthritis, using an immunofluorescent sandwich technique, and was found to be similar to that in osteo-arthritic controls matched for age and sex. The prevalance in various other forms of arthritis was also found to be low.

Twelve patients with rheumatoid arthritis and positive tests for gastric parietal-cell autoantibody were selected for further study. The gastric parietalcell autoantibody was shown in these patients to be organ-specific by exclusion of sera containing nonspecific autoantibody demonstrable by testing against rat kidney and human thyroid gland. Augmented histamine test meals in these patients showed significant impairment of gastric acid secretion as compared with fourteen age- and sex-matched controls with rheumatoid arthritis and negative tests for gastric parietal-cell autoantibody. No correlation was found between gastric secretory function and past or present drug therapy.

It is concluded that there is no increased prevalance of gastric parietal-cell autoantibodies in rheumatoid arthritis, but that when this autoantibody is present it is organ-specific and reflects chronic atrophic gastritis with histamine-fast hypochlorhydria.

I gratefully acknowledge the receipt of a research grant from the Arthritis and Rheumatism Council without which this work would not have been possible. My thanks are due to Dr. R. B. Goudie and Dr. R. N. M. McSween of the University Department of Pathology, Western Infirmary, Glasgow, for guidance in the immunological aspects of this study, and to Dr. J. A. Boyle, Dr. W. W. Buchanan, and Dr. M. K. Jasani of the University Department of Medicine and the Centre for Rheumatic Diseases, Baird Street, Glasgow, for advice and encouragement in the clinical aspects. I must also mention the invaluable assistance afforded to me at all times by the staff of the Regional Immunopathology Laboratory and by the Sisters and nursing staff of the Centre for Rheumatic Diseases.

\section{REFERENCES}

Adams, J. F., Glen, A. I. M., Kennedy, E. H., Mackenzie, I. L., Morrow, J. M., Anderson, J. R., Gray, K. G., and Middleton, D. C. (1964). Lancet, 1, 401 (The histological and secretory changes in the stomach in patients with autoimmunity to gastric parietal cells).

Alexander, W. R. M., Bremner, J. M., and Duthie, J. J. R. (1960). Ann. rheum. Dis., 19, 338 (Incidence of the anti-nuclear factor in human sera).

Anderson, J. R., Beck, J. S., Bloch, K., Buchanan, W. W., and Bunim, J. J. (1965). "Autoimmunity": Symposium of 5th Congress of International Academy of Pathology, ed. R. W. Baldwin and J. H. Humphrey, p. 26. Blackwell, Oxford.

—_, J. R., Goudie, R. B., Gray, K. G., and Buchanan, W. W. (1961). Scot. med. J., 6, 449 (Antibody to thyroglobulin in patients with collagen diseases).

Ballabio, C. B., Cirla, E., Girardi, G., Caruso, I., and Colombo, B. (1963). Reumatismo, 15, 487 (Effetti clinici e metabolici dell' indomethacin nelle malattie reumatiche).

Beck, J. S. (1961). Lancet, 1, 1203 (Variations in the morphological patterns of "Autoimmune" nuclear fluorescence).

— (1963). Scot. med. J., 8, 373 (Auto-antibodies to cell nuclei).

Becker, K. L., Ferguson, R. H., and McConahey, W. M. (1963). New Engl. J. Med., 268, 277 (The connective-tissue diseases and symptoms associated with Hashimoto's thyroiditis).

—, Titus, J. L., Woolner, L. B., and Ferguson, R. H. (1963). Proc. Mayo Clin., 38, 125 (Thyroiditis and rheumatoid arthritis).

Bernhardt, H., Burkett, L. L., Fields, M. L., and Killian, J. (1965). Ann. intern. Med., 63, 635 (The diagnostic significance of the parietal cell immunofluorescence test).

Buchanan, W. W., Crooks, J., Alexander, W. D., Koutras, D. A., Wayne, E. J., and Gray, K. G. (1961). Lancet, 1, 245 (Association of Hashimoto's thyroiditis and rheumatoid arthritis).

Card, W. I., and Marks, I. N. (1960). Clin. Sci., 19, 147 (The relationship between the acid output of the stomach following "maximal" histamine stimulation and the parietal cell mass). 
Coghill, N. F., Doniach, D., Roitt, I. M., Mollin, D. L., and Wynn Williams, A. (1965). Gut, 6, 48 (Autoantibodies in simple atrophic gastritis).

Co-operating Clinics Committee of the American Rheumatism Association (1965). Arthr. and Rheum., 8, 302 (A seven-day variability study of 499 patients with peripheral rheumatoid arthritis).

Dagg, J. H., Goldberg, A., Anderson, J. R., Beck, J. S., and Gray, K. G. (1964). Brit. med. J., 1, 1349 (Autoimmunity in iron-deficiency anaemia).

De Boer, W. G. R. M., Nairn, R. C., and Maxwell, A. (1965). J. clin. Path., 18, 456 (Pernicious anaemia autoantibody to gastric parietal cells: immunofluorescence test with rat stomach).

Doniach, D., Roitt, I. M., and Taylor, K. B. (1963). Brit. med.J., 1, 1374 (Autoimmune phenomena in pernicious anaemia: Serological overlap with thyroiditis, thyrotoxicosis, and systemic lupus erythematosus).

Glynn, L. E., and Holborow, E. J. (1960). Ann. rheum. Dis., 19, 197 (Immunological aspects of rheumatoid disease: a review).

Goudie, R. B., and Buchanan, W. W. (1967). Scot. med. J., 12, 87 (Autoimmunity in rheumatoid arthritis).

Hall, A. P., Bardawil, W. A., Bayles, T. B., Mednis, A. D., and Galins, N. (1960). New. Engl. J. Med., 263, 769 (The relations between the antinuclear, rheumatoid and L.E.-cell factors in the systemic rheumatoid diseases).

Heller, G., Jacobson, A. S., Kolodny, M. H., and Kammerer, W. H. (1954). J. Immunol., 72, 66 (The heamagglutination test for rheumatoid arthritis: II. The influence of human plasma fraction II (gamma globulin) on the reaction).

Hijmans, W., Doniach, D., Roitt, I. M., and Holborow, E. J. (1961). Brit. med. J., 2, 909 (Serological overlap between lupus erythematosus, rheumatoid arthritis, and thyroid auto-immune disease).

Irvine, W. J. (1965). New Engl. J. Med., 273, 432 (Immunologic aspects of pernicious anemia).

- (1966). Proc. roy. Soc. Med., 59, 695 (Clinical and pathological significance of parietal cell antibodies).

-, Davies, S. H., Delamore, I. W., and Wynn Williams, A. (1962). Brit. med. J., 2, 454 (Immunological relationship between pernicious anaemia and thyroid disease).

- - - Teitelbaum, S., Delamore, J. W., and Wynn Williams, A. (1965). Ann. N.Y. Acad. Sci., 124, 657 (The clinical and pathological significance of gastric parietal cell antibody).

Kay, A. W. (1953). Brit. med. J., 2, 77 (Effect of large doses of histamine on gastric secretion of $\mathrm{HCl}$-an augmented histamine test).

Kirsner, J. B., and Ford, H. (1955). Gastroenterology, 29, 1 (Phenylbutazone (Butazolidin)studies in the stimulation of gastric secretion and the formation of peptic ulcer in man).

Kornstad, L., and Kornstad, A. M. G. (1964). Acta rheum. scand., Suppl. "V Europ. Congr. Rheum., Stockholm, 1963", p. 77. (Thyroid autoimmunization in patients suffering from rheumatoid arthritis and ankylosing spondylitis and in presumably healthy persons).

Marks, I. N., Komarov, S. A., and Shay, H. (1960). Amer. J. Physiol., 199, 579 (Maximal acid secretory response to histamine and its relation to parietal cell mass in the dog.)

Markson, J. L., and Moore, J. M. (1962). Lancet, 2, 240 (Autoimmunity in pernicious anaemia and iron deficiency anaemia).

Masi, A. T., Hartmann, W. H., Hahn, B. H., Abbey, H., and Shulman, L. E. (1965). Ibid., 1, 123 (Hashimoto's disease: a clinicopathological study with matched controls: lack of significant associations with other "autoimmune" disorders).

Mauer, E. F. (1955). New Engl. J. Med., 253, 404 (The toxic effects of phenylbutazone (Butazolidin). Review of the literature and report of the 23rd death following its use).

Moore, J. M., and Neilson, J. M. (1963). Lancet,',2, 645 (Antibodies to gastric mucosa and thyroid in diabetes mellitus).

Mulhern, L. M., Masi, A. T., and Shulman, L. E. (1966). Ibid., 2, 508 (Hashimoto's disease. A search for associated disorders in 170 clinically detected cases).

Pitkeathly, D. A., and Taylor, G. (1967). Ann. rheum. Dis., 26, 1 (Antinuclear factor in rheumatoid arthritis and related diseases).

Roitt, I. M., Doniach, D., and Shapland, C. (1965). Ann. N.Y. Acad. Sci., 124, 644 (Autoimmunity in pernicious anemia and atrophic gastritis). 
Ropes, M. W., Bennett, G. A., Cobb, S., Jacox, R., and Jessar, R. A. (1959). Ann. rheum. Dis., 18, 49 (Diagnostic criteria for rheumatoid arthritis: 1958 Revision).

Rothermich, N. O. (1966). J. Amer. med. Ass., 195, 1102 (An extended study of indomethacin II. Clinical therapy).

Scott, J. T., Porter, I. H., Lewis, S. M., and Dixon, A. St.J. (1961). Quart. J. Med., 30, 167 (Studies of gastrointestinal bleeding caused by corticosteroids, salicylates, and other analgesics).

Singer, J. M. (1961). Amer. J. Med., 31,766,(The latex fixation test in rheumatic diseases. A review).

Taylor, K. B., Roitt, I. M., Doniach, D., Couchman, K. G., and Shapland, C. (1962). Brit. med. J., 2, 1347 (Autoimmune phenomena in pernicious anaemia: gastric antibodies).

Vaughan, J. H., and Butler, V. P., Jr.J(1962). Ann. intern. Med., 56, 1 (Current status of the rheumatoid factor).

Ward, D. J., Johnson, G. D., and Holborow, E. J. (1964). Ann. rheum. Dis., 23, 306 (Antinuclear factor in rheumatoid arthritis. Its incidence and clinical significance.)

Weiss, A., Pitman, E. R., and Graham, E. C. (1961). Amer. J. Med., 31, 266 (Aspirin and gastric. bleeding. Gastroscopic observations, with review of literature).

Williams, M. J., Scott, G. B., Beck, J. S., and Blair, D. W. (1966). Brit. med. J., 1, 388 (Antigastric antibodies in hyperthyroidism: their relationship to impaired acid secretion).

Ziff, M. (1957). J. chron. Dis., 5, 644 (The agglutination reaction in rheumatoid arthritis).

Une étude de la fréquence et de la signification des autoanticorps anti-muqueuse gastrique dans l'arthrite rhumatismale

\section{RÉSUMÉ}

On étudia la fréquence avec laquelle on trouvait des autoanticorps anti-muqueuse gastrique chez des malades atteints d'arthrite rhumatismale en utilisant le procédé d'immunofluorescence "en sandwitch" et on trouva des résultats comparables à ceux des témoins ostéoarthrosiques compte tenu de l'âge et du sexe. De même, cette fréquence fut basse dans d'autres formes d'arthrite.

On retint pour une étude ultérieure douze malades atteints d'arthrite rhumatismale chez lesquels on avait trouvé des autoanticorps anti-muqueuse gastrique. Chez ces malades on démontra que les autoanticorps antimuqueuse gastrique étaient spécifiques de l'organe en éliminant les sérums contenant des autoanticorps non spécifiques, identifiés par leur action sur le rein de rat et sur la thyroïde humaine. L'épreuve à l'histamine montra chez ces malades une inhibition significative de la secrétion gastrique acide par rapport à 14 témoins d'âge et de sexe comparables ayant une arthrite rhumatismale mais pas d'autoanticorps anti-muqueuse gastrique. On n'a pas trouvé de corrélation entre la fonction secrétoire gastrique et l'absorption passé ou présente de médicaments.

On conclut que la fréquence d'autoanticorps antimuqueuse gastrique n'est pas augmentée dans l'arthrite rhumatismale, mais quand ces autoanticorps existent, ils sont spécifiques de l'organe et présentent une manifestation d'une gastrite atrophique chronique avec hypochlorhydrie résistante à l'histamine.
Una investigación de la frecuencia y del significado de los autoanticuerpos contra la mucosa gástrica en la artritis reumatoide

\section{SUMARIo}

Se estudió la incidencia del autoanticuerpo contra la mucosa gástrica en enfermos con artritis reumatoide, empleando el procedimiento de inmunofluorescencia "en sandwich"; los resultados hallados fueron similares a los obtenidos en testigos osteoartrósicos, con tener cuenta de la edad y del sexo. La incidencia en varias otras formas de artritis fué también baja.

Se escogieron para una investigación ulterior doce enfermos con artritis reumatoide y con auto anticuerpos contra la mucosa gástrica comprobados. Se demostró en estos enfermos que los autoanticuerpos contra la mucosa gástrica fueron específicos del órgano por exclusión de los sueros con autoanticuerpos no específicos, identificados por reacciones contra el riñon de rata y la glándula tiroidea humana. Pruebas de la histamina evidenciaron en estos enfermos una inhibición significativa de la secreción gástrica ácida en comparación con 14 testigos de edad y de sexo comparables, afectos de artritis reumatoide sin autoanticuerpo contra la mucosa gástrica. No se halló correlación alguna entre la función secretoria gástrica y la terapéutica medicamentosa pasada o presente.

Se concluye que la incidencia de autoanticuerpos contra la mucosa gástrica no se ve aumentada en la artritis reumatoide, pero los autoanticuerpos que existen son específicos del órgano y reflejan una gastritis atrófica crónica con hipoclorhidria resistente a la histamina. 